\title{
Job Satisfaction as a Mediator between Directive and Participatory Leadership Styles toward Organizational Commitment
}

\author{
Humuntal Banjarnahor \\ Dr., State University of Medan, Indonesia, humbanjarnahor@gmail.com
}

Wesly Hutabarat

Prof., corresponding author, State University of Medan, Indonesia. barathuta@gmail.com

\author{
Abdul Muin Sibuea \\ Prof., State University of Medan, Indonesia,muin_sibuea@gmail.com

\section{Manihar Situmorang} \\ Prof., State University of Medan. Indonesia, msitumorang@lycos.com
}

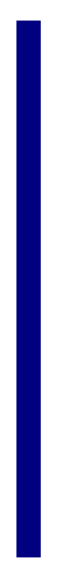

Principals play a very important role in determining the quality of education in schools. The success of the principals to mobilize all potential in the school environment is highly dependent on the leadership styles. Job satisfaction and organizational commitment of the principals, teachers and administrators are considered as indicators in determining the success of the school institution. The objective of the research was to investigate the role of job satisfaction as a mediator in influencing the directive and participative leadership styles toward the elementary school principal organizational commitments in Medan. The sample of the research was 164 junior high school principals of the school principals selected and the data analyzed with path analysis. The results showed that (1) the principal job satisfactions did not function positively as a mediator between directive leadership styles and organizational commitments, (2) job satisfaction found as a positive mediator between participative leadership styles and principal organizational commitment.

Keywords: jobs satisfaction, leadership styles, mediator, organizational commitments, leadership

\section{INTRODUCTION}

Educational institutions should be considered as the center of excellence in the overall discourse of human resource development. To support this, the primary responsibility lies on the principal as a key factor affecting the effectiveness of schools and the

Citation: Banjarnahor, H., Hutabarat, W., Sibuea, A. M., \& Situmorang, M. (2018). Job Satisfaction as a Mediator between Directive and Participatory Leadership Styles toward Organizational Commitment. International Journal of Instruction, 11(4), 869-888. https://doi.org/10.12973/iji.2018.11455a 
difference between a high-performing school and a low-performing school is due to the influence of the principals (Sudarmin, 2012). This shows that the headmaster's leadership style determines the school effectiveness, but in reality the headmasters in Indonesia have not performed their duties and functions in accordance with the rules and regulations (Nuh, 2011)

Hirsch \& Emerick \& Church et al (2006) found that when School leaders who successfully empower teachers, create safe school environments and develop supportive, trusting climates will be able to promote student learning, and reported that teacher perceptions of working conditions could be considered as predictors of student achievement. Therefore, classroom and school condition are viewed as essential factors to students achievement. Patrick (2007) reported that teachers who are satisfied with their work are more enthusiastic and interested in devoting more energy and time to enhance student achievements. Hirsch and Emerick et al (2006) also reported that improving teacher working conditions such as time, professional development, leadership, empowerment, and facilities and resources will improve student learning conditions. Therefore, information about the important factor affecting teacher work satisfactions is highly important to support the increase of the student achievements, one of which is the behavior or leadership style of the principals (Stogkard \& Leman, 2004). Principals who involved teachers in decision making would have a positive effect on their motivations and commitments in doing their jobs so that the learning effectiveness and efficiency are influenced by the principal leadership styles (Bogler, 2001; Hui, et.al. 2012; Thian, 2014).

Appreciation on teacher works are a contributing factor to improve job satisfactions, because the teachers feel appreciated by the community and government so that it will grow a sense of self-esteem and commit to their institutions and works (Colquit \& Le Pine \& Wesson, 2009). Mulyasa, (2013) argued that the success or failure of education and learning in schools is strongly influenced by the ability of the principal in managing the staffs and teachers. Reza (2013) reported that leadership style of an organization has a positive relationship with the level of job satisfaction of his/her subordinates so that the leader must have the ability to manage the environments to improve organizational performance effectively, improve the quality of his/her subordinate's life and achieve the organizational goals (Gilbreath, 2013). Leadership style, job satisfaction and organizational commitment are the variables considered as potential research variables, because the variables are strategic variables in an organization in measuring organizational success, including in school institutions (Cemaloglu \& Sezgin, et al. 2012). Job satisfaction variable is considered as a mediator of leadership style with organizational commitment (Colquit, et.al., 2009; Sušanj \& Jakopec, 2012).

Stuard Wetson as co-PDBE3 (Project Decentralized Basic Education-3) stated that to improve the quality of education requires a commitment to education in North Sumatra, because individual commitment in education is an important factor affecting the quality of education (Bahrumsyah, 2009). It was found that the commitment of elementary school principals in Medan was classified relatively good, it was considerably apprehensive because organizational commitment is considered as an indicator of the 
school principal success in managing the schools (Bintang, 2011). This principal commitment condition reflected low loyalty, low hard work to achieve school goals, has not obeyed the school regulations and there was a possibility to work in other institutions (dual jobs).

The path goal model theory leadership styles can be used to lead the teachers and staffs based on directive, participatory, supportive, and goal styles, in which a leader must be able to sort and choose his style according to the characteristics of work and subordinates (Robbin \& Coulter, 2007). Participative and supportive styles characterize democratic and directive styles and goal orientations tend to characterize autocratic dictatorships. Therefore the directive or participative styles are presumed to be highly effective in managing school organizations.

\section{Hypotheses}

1. There is a direct effect between the Principal Directive Leadership Style and Principal JobSatisfaction.

2. There is a direct effect between the Principal Directive Leadership Style and Principal Organizational Commitments.

3. There is a direct effect between the Principal Participative Leadership Style and Principal Job-Satisfaction

4. There is a direct effect between the Principal Directive Leadership Style and Principal Organizational Commitments.

5. There is a direct effect between the Job-satisfaction and Principal Organizational Commitments.

6. There is an indirect effect between the Directive Leadership Style and Organizational Commitments through Job-satisfaction.

7. There is an indirect effect between the Participative Leadership Style and Organizational Commitments through Job-satisfaction.

\section{Objective of the Study}

Based on the above description above, it is necessary to find out:

1. Whether job satisfaction could serve as a positive mediator between the directive leadership style and the organizational commitment of the junior high school principals.

2. Whether job satisfaction could serve as a positive mediator between the participative leadership style and the organizational commitment of the Junior high school principals.

\section{LITERATURE STUDIES}

\section{Directive Leadership Style}

Bell, Chan \& Nel. (2014) defined directive leadership as a process of providing guidance to subordinates in taking decisions and actions that support leadership goals, tends to control discussions, dominates interaction, and task-oriented. Mahdi, Gulam \& Almsafir (2014) asserted emphatically that directive leadership directs work processes such as "what to do", "how to do", "where", "when," and "who should do" is clearly defined, but directive leadership shows concern for the welfare of subordinates and personal needs (Mahdi,et.al., 2014; Maqsood, Bilal \& Nazir,2013; Malik, Naswab, \& Naeem, 2010; Rani, Jeyakkumaran \& Reddy, 2013). 
Robbin (2008) argued that directive leadership styles positively affect work satisfaction of the organizational members, when member tasks are ambiguous or stressful, but not for members with high ability and experience. Further Murdoch (2013) stated that the characteristic of directive-style leaders is to act aggressively, controlled, descriptive, and structured and tend to dictate subordinates about what to do and how to do. Directive style positively correlates with subordinate satisfaction in performing ambiguous tasks, but negatively related to subordinate satisfaction that performs structured work and taks oriented but negatively correlated $(\mathrm{r}=-0.47)$ with organizational commitment (Cokluk \& Yilmaz, 2010; Nadarasa \& Thuraisingam, 2014). Mahdi, et al (2014) found that leadership styles affect organizational commitment, and directive and supportive leadership styles have an important role in influencing organizational commitment of organizational members. Somech (2005) also found that directive leadership is related to organizational commitment, with a coefficient of determination of 0.17 and its relationship to performance of $r^{2}=0.26$. While participatory style associated with staff innovation, with $r^{2}=0.19$ and empowerment of $r^{2}=0.19$. Cokluk et al (2010) showed that, directive leadership is positively correlated with organizational commitment, affective commitment and continuance commitment with determinant coefficient of $\mathrm{r}^{2}=$ $0.22, \mathrm{r}^{2}=0.23$, and $\mathrm{r} 2=0.07$ respectively.

\section{Participatory Leadership Style}

The participative leadership style is one of the "path goal model" leadership styles developed by House and Mitchell (1974). Silong, Hassan and Madina (2009) stated that one of the leadership styles that can contribute to effective leadership activities is the participative leadership style. Participatory leadership is a leadership that involves subordinates in decision making, consulting with employees, collecting ideas and subordinates into considerations before making decisions, consulting with subordinates about matters relating to work, asking for subordinate opinions, and often try to use ideas subordinates in decision making (House, et al. 1974; Robbin, 2008; Murdoch, 2013).

Principals of participatory style are considered to foster job satisfaction of the teachers, because they are participated to formulate school goals, how to achieve the goals, and what needs are required to achieve the goals. The participatory leadership style of the principal is significantly positively related to teacher performance efficiency (Jalilizadeh., Abbasi \& Sardar (2013) helping teachers to discover new opportunities and challenges and enable them to learn, acquire, share and combine knowledge (Edmondson, 1999) as well as engaging teachers to face and solve these opportunities and challenges simultaneously, thereby improving teacher performance and satisfaction (Benoliel \& Somech, 2010; Rotich \& Kipkoech, 2012). The participative leadership style contributes to awareness of members to actively engage in their work. Furthermore, Huang (2011) found that participative leadership style positively related with teacher commitments.

\section{Job Satisfaction}

Satisfaction is a psychological atmosphere that does not have a universal standard size that applies to everyone. Job satisfaction is a person's sense of evaluation of his work, 
assessment of how well his job satisfies his needs, how his assessment of the job or how it is assessed for individual social relations outside the work, or measures of organizational success in meeting the needs of subordinates (Robbin \& Judge, 2005; Gipson, 2006; Veithzal \& Mulyadi, 2011). The most important indicators of job satisfaction are the work itself, wages or salaries, co-workers, supervision, promotion, and working conditions (Colquit, 2009; Luthan, 1998).

Furthermore Reza (2013) found that the variables of leadership style, organizational commitment, and job satisfaction are the variables that are positively related significantly in an organization. In addition, Malik et all (2010) and Getahun, (2016) found that there is a positive relationship between teachers' job satisfaction and organizational commitment. This finding is also in line with the findings of Shan, 1998; Damstad, 2004; Tain-Fung \& Mei-Hui, et al. 2006 ; and Sweeney \& Quirin, 2009.

\section{Organizational Commitment}

Organizational commitment is a psychological state that characterizes employees' relationships with the organization or its implications that affect whether employees will survive in the organization or not (Zurnali, 2010). Malik, et al (2010) studied on one of the teacher universities in Pakistan showed that satisfaction with the quality of supervision and satisfaction of salary have a significant positive effect on organizational commitment. Commitment is an important factor in an organization, because commitment plays a role to form a unity of work teams that have an impact to improve performance to achieve organizational goals (Clark, 1996)). The organizational commitment is characterized by: (1) the desire to remain in a particular organization, (2) the desire to hard work to achieve the organization goals, (3) as well as willingness to accept the organizational values and beliefs (Meyer \& Allen, 1991; Mowday, Steer \& Porter, 1979).

Based on the above description that the level of the organizational commitment is a factor that can be considered as a measure of success of an organization, and many research findings indicated that lack of organizational commitment can reduce organizational effectiveness (Gipson, Ivancevich \& Donnelly, 1996). Further, Luthan (2006) classified the organizational commitment into three components: (1) affective commitment, ie, the emotional commitment of workers to the organization; (2) continuance commitment, ie commitment based on losses related to the number of employees who remain in the organization; 3) normative commitment that is a mandatory feeling to try to remain in the organization. The organizational commitment therefore is useful to maintain employees staying in the organization, and responsible for maintaining organizational productivities. If there is a low level of organizational commitment, it could lead employees to resigning from the organization. As a result, the organization would spend a lot money and time to recruit new employees and resulting in low productivity.

\section{METHOD}

Method of research was survey research method where participants answer questions distributed to sample selected. 


\section{Location and Sample selection}

The questionnaires consisted of open ended questionnaires. The study was conducted in junior high school in Medan, North Sumatra, Indonesia. The study population was 403 the junior high school principals consisting of 45 Public Junior High Schools and 358 Private Junior High Schools. The sample randomly selected was 164 of the 403 school principals. The sample selected consisted of 150 school principals who have teaching experiences 30 years and the rest have teaching experiences of at least 20 years, as shown in Table 1 below:

Table 1

Selected Sample Classifications

\begin{tabular}{|c|c|c|c|c|}
\hline \multirow[t]{2}{*}{ Junior School Principals } & \multicolumn{4}{|c|}{ Teaching Experiences } \\
\hline & \multicolumn{2}{|c|}{20 years } & \multicolumn{2}{|c|}{30 Years } \\
\hline \multirow[t]{2}{*}{ 1. Public schools } & Male & Female & Male & Female \\
\hline & 6 & 1 & 10 & 10 \\
\hline \multirow[t]{2}{*}{ 2. Private schools } & Male & Female & Male & Female \\
\hline & 5 & 2 & 90 & 40 \\
\hline
\end{tabular}

\section{Research Instruments}

The research instrument consisted of directive and participative leadership questionnaires, job satisfaction and organizational commitment questionnaires. Instruments were developed based on the indicators formulated of the operational definition of the variables. The research instruments were based on Likert's Scale which consisted of 40 items with 5 options. The instruments were tried out and found the directive leadership style questionnaires (based on the Daft's directive leadership behaviors i.e. planning, setting schedules, performance, goals, and behavior standard, obeying the rules and regulations using 7 scales ie, using 7 scales ie, strongly disagree $(\mathrm{SD}=1)$; moderately disagree $(\mathrm{MD}=2)$; slightly disagree $(\mathrm{LD}=3)$; neither disagree nor agree $(\mathrm{O}=4)$; slightly agree $(\mathrm{LA}=5)$; moderately agree $(\mathrm{MA}=6)$; strongly agree $(\mathrm{SA}=7)$, participative leadership questionnaires (based on Daft's participative leadership descriptions i.e. sense ownership for their job, appreciation of others needs and perspectives, trust people opinions, collaboration and good intentions using 7 scales ie strongly disagree $(\mathrm{SD}=1)$; moderately disagree $(\mathrm{MD}=2)$; slightly disagree $(\mathrm{LD}=3)$; neither disagree nor agree $(\mathrm{O}=4)$; slightly agree $(\mathrm{LA}=5)$; moderately agree $(\mathrm{MA}=6)$; strongly agree $(\mathrm{SA}=7)$, job satisfaction questionnaires (based on the Michelle's Job Descriptive Index (JDI) i.e. salary, promotion, supervision, and colleagues, using 7 scales "very satisfied (VS=7), satisfied $(S=6)$, somewhat satisfied $(\mathrm{SS}=5)$; not important $(\mathrm{NI}=4)$; somewhat unsatisfied $(\mathrm{SU}=3)$; unsatisfied $(\mathrm{US}=2)$; and very unsatisfied $(\mathrm{VU}=1)$ ), and organizational commitment questionnaire (based on the Mowday's Organizational Commitment Questionnaires using 7 scales ie, strongly disagree $(\mathrm{SD}=1)$; moderately disagree $(M D=2)$; slightly disagree $(L D=3)$; neither disagree nor agree $(\mathrm{O}=4)$; slightly agreen $(\mathrm{LA}=5)$; moderately agree $(\mathrm{MA}=6)$; strongly agree $(\mathrm{SA}=7))$, validated were 30,28, 27 and 31 items respectively presented in Table 2. 
Tabel 2

Validity and Reliability test tried out

\begin{tabular}{llll}
\hline Research instruments & Items tried out & items Valid & Cronbach coefficients - Alpa $(\alpha)$ \\
\hline Directive Style & 40 & 30 & 0,925 \\
\hline Participative Style & 40 & 28 & 0,926 \\
\hline Job Satisfaction & 40 & 27 & 0,877 \\
\hline Org. Commitment & 40 & 31 & 0,888 \\
\hline
\end{tabular}

\section{Data Analysis}

Data analysis was carried out by using path analysis. The theoretical model to be tested in the study was presented in Figure 1 which consisted of Sub-structure-1 (Figure 1a), Sub-structure-2 (Figure 1b) and Sub-structure-3 (Figure 1c). The variables were directive leadership style $\left(X_{1}\right)$, participative leadership style $\left(X_{2}\right)$, job satisfaction $\left(X_{3}\right)$, and organizational commitment $\left(\mathrm{X}_{4}\right)$ of the school samples selected.

Figure 1

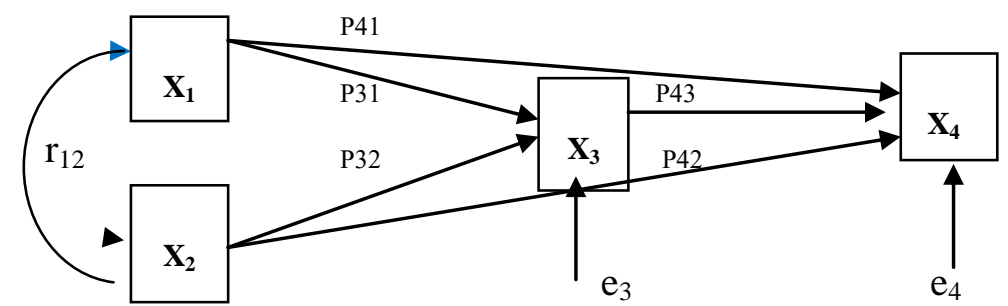

Theoretical model of the investigated variables

The causal relationships between the variables could be classified into three substructures as shown below:

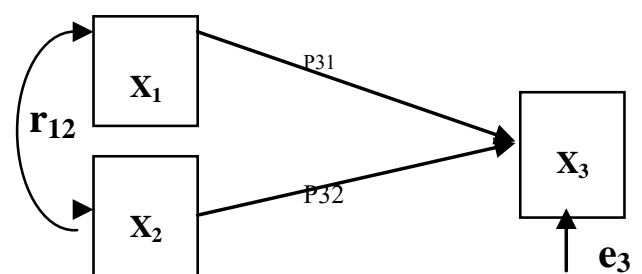

Figure 1a

Sub-structure-1

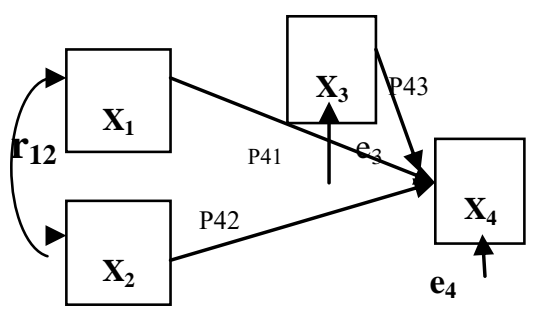

Figure 1b

Sub-structure-2

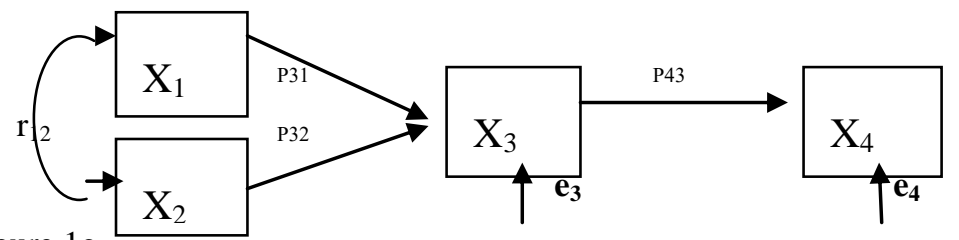

Figure 1c

Sub-structue-3 


\section{FINDINGS}

\section{Data Descriptions}

The average data scores of the directive leadership style $\left(\mathrm{X}_{\overline{1}_{1}}\right)=3.00$; participatory leadership style $\left(\mathrm{X}_{2}^{-}\right)=2.79$; job satisfaction $\left(\mathrm{X}_{3}^{-}\right)=2.94$; and organizational commitment $\left(\mathrm{X}_{4}^{-}\right)=3.21$. Standard deviation of the $\left(\mathrm{X}_{1}^{-}\right),\left(\mathrm{X}_{2}^{-}\right),\left(\mathrm{X}_{3}^{-}\right)$and $\left(\mathrm{X}_{4}^{-}\right)$ variables were $0.94,0.88,0.90$ and 0.87 respectively. It means that, on average that the participatory and directive leadership styles, job satisfaction and organizational commitment of the principals are presumably as moderate category.

Analysis of the 164 data showed that $18.90 \%$ of the principal directive style was classified as high category, $61.59 \%$ moderate category, $18.29 \%$ low category and $1.21 \%$ very low category, however there was no principal that had the directive leadership style in very high category. In addition, it was also found that $1.83 \%$ of the principals who had a participatory leadership style in very high category, $17.68 \%$ in high category, $61.59 \%$ in moderate category and $18.90 \%$ in low category levels.

When looking at principal's job-satisfaction, it was also found that there was no principals who had job-satisfaction in very high category level, but $17.07 \%$ of them classified as high category, $64.03 \%$ as moderate category, $17.68 \%$ as low category and $1.22 \%$ in very low category. It was found that $17.07 \%$ of principal's organizational commitment classified as high category, $65.85 \%$ at moderate category, $14.03 \%$ at low category and $3.05 \%$ at very low level. There was no principal who had job-satisfaction, organizational commitment, and directive leadership styles at very high category level The results could be plotted into a bar diagram below.

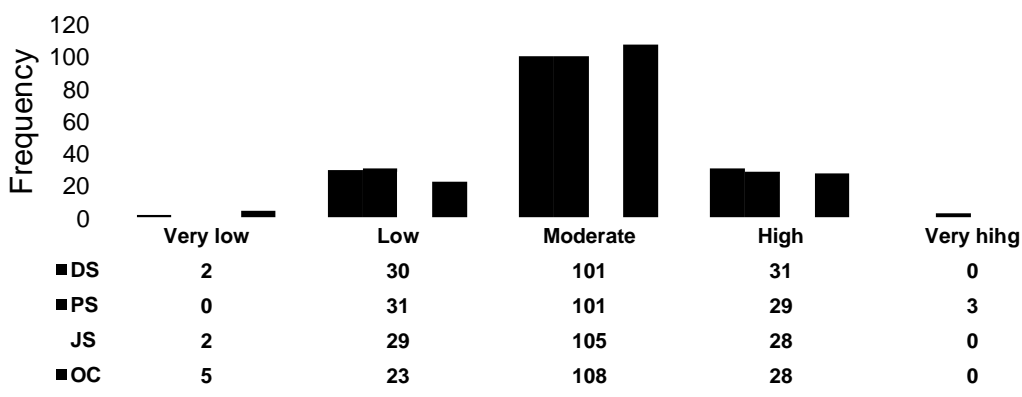

Figure 2

Bar diagram of the distribution frequency

\section{Job Satisfaction and Organizational Commitment}

Tendency of job satisfaction (JS) and organizational commitment (OC) based on low directive style (LDS), moderate directive style (MDS) and high directive leadership styles (HDS) were presented in Figure 3. The JS regression of the DS category is: $\mathrm{Y}_{\mathrm{JS}}=$ $-0,53 \mathrm{X}+4,033$ and $\mathrm{OC}$ regression on the DS category is: $\mathrm{Y}_{\mathrm{OC}}=0,135 \mathrm{X}+2,973$. Descriptions of both regressions showed that the principals with low directive style (LDS) had higher JS than OC (ie 3.53 and 3.14), but not in the other two categories. 
In the moderate directive style category, it was found that JS was smaller than OC (ie 2.92 and 3.18); as well as in the high directive style (HDS) category (ie 2.47 and 3.41). This phenomenon means that the higher the DS scores, the lower the job satisfaction but tends to be higher in the organizational commitment.

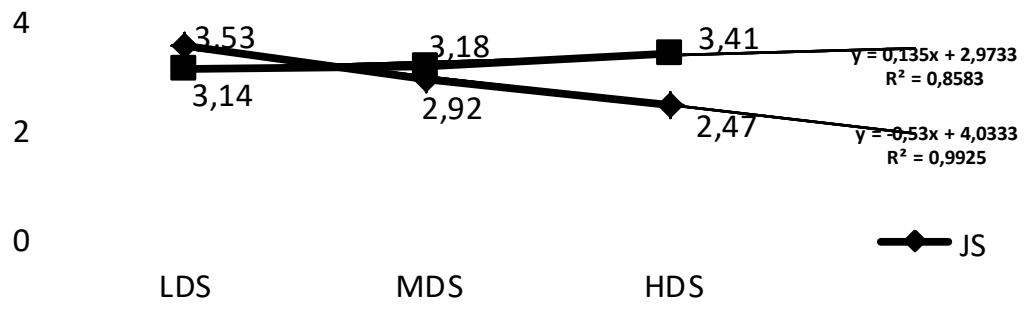

Figure 3

JS and OC tendency based on directive leadership style

On the contrary, the principal who had a participative leadership style (PS), tended to be positively correlated with JS and OC (Figure 4). The JS regression on the PS variable was: $\mathrm{Y}_{\mathrm{JS}}=0.795 \mathrm{X}+1.296$ and the $\mathrm{OC}$ regression on the $\mathrm{PS}$ variable was: $\mathrm{Y}_{\mathrm{OC}}=0.970 \mathrm{X}$ +1.423 . From the two equations, it could be determined that the higher the participative leadership scores the higher the job satisfaction and organizational commitment.

The change in the principal organizational commitment tended to be greater than job satisfaction for the same category of the participative style (PS). For example, the predicted OC and JS in the high participative style (HPS) category were 4.44 and 3.57 respectively. Principals with a moderate participative style (MPS) had a relatively scores of JS and OC (ie 3.11 and 3.15). This indicated that the intensity of leadership in the MPS was moderately limited to JS and OC. Principals in the MPS category had relatively similar JS and OC values (ie 3.15 and 3.11) but the low participative style (LPS) had significant lower values (ie, 2.50 and 1.98). This showed that the participative leadership gave a positive impact on the job satisfaction and organizational commitment differently.

6

4

2

0

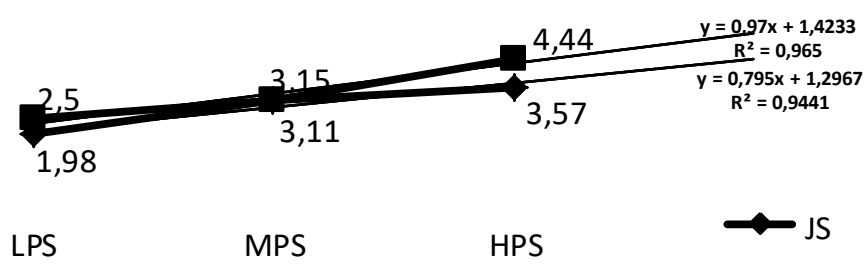

Figure 4

Tendency of JS and OC based on the Participatory Leadership style

\section{Normality and Linearity Tests}

Normality and linearity tests were carried out with SPSS 20 for Windows and the results are presented in Table 3 below. 
Table 3

Normality and Linearity Test Results

\begin{tabular}{|c|c|c|c|c|}
\hline Variables & Regression & \begin{tabular}{l|l|}
$\operatorname{Max}$ & $\mathrm{F}\left(\mathrm{Z}_{\mathrm{i}}\right)-\mathrm{S}\left(\mathrm{Z}_{\mathrm{i}}\right) \mid$
\end{tabular} & $\mathrm{F}_{\text {cal }}=\frac{S S t / 35}{S S e / 127}$ & Conclusions \\
\hline $\mathrm{X}_{1}$ and $\mathrm{X}_{3}$ & $\widehat{\mathrm{X}}_{3}=3,896-0,316 \mathrm{X}_{1}$ & 0,0721 & 0,880 & Normal and linear \\
\hline $\mathrm{X}_{2}$ and $\mathrm{X}_{3}$ & $\widehat{\mathrm{X}}_{3}=2,289+0,235 \mathrm{X}_{2}$ & 0,0729 & 0,991 & Normal and linear \\
\hline $\mathrm{X}_{1}$ and $\mathrm{X}_{4}$ & $\widetilde{\mathrm{X}}_{4}=2,619+0,199 \mathrm{X}_{1}$ & 0,0633 & 1,628 & Normal and linear \\
\hline $\mathrm{X}_{2}$ and $\mathrm{X}_{4}$ & $\widehat{\mathrm{X}}_{4}=2,244+0,348 \mathrm{X}_{2}$ & 0,0294 & 1,611 & Normal and linear \\
\hline $\mathrm{X}_{3}$ and $\mathrm{X}_{4}$ & $\overline{\mathrm{X}}_{4}=2,649+0,192 \mathrm{X}_{3}$ & 0,0631 & 0,800 & Normal and linear \\
\hline
\end{tabular}

From the Table 3 above, it can be seen that the value of $L=\max |\mathrm{F}(\mathrm{Zi})-\mathrm{S}(\mathrm{Zi})|$ $<\mathrm{L} 0,01(164)=0,0805$ and the value of $\mathrm{F}<\mathrm{F}(35 ; 127)=1,86$; meant that all of the five regressions were linear and normally distributed.

\section{Hypothesis Testing}

The correlation coefficients between the variables calculated with the SPSS 20 for Windows were: $r_{12}=-0,077 ; r_{13}=-0.330 ; r_{14}=0.216 ; r_{23}=0,231 ; r_{24}=0.355 ; r_{34}=0$. 200 and it turns out to be significant at the 0.01 level except for $r_{12}$. This suggests that there was no collinearity between the principal directive and participative leadership styles.

By using a recursive equation to find out the theoretical model and path coefficient ( $\rho \mathrm{ji}$ ) describing the causal relationship structure between directive leadership style, participative leadership style, and job satisfaction as the exogenous variable or moderator toward the organizational commitment of the junior high school principals was presented in Figure 5. Path coefficient of DS towards JS, DS towards OC, PS towards JS, PS towards OC and JS toward OC were $-0.352,0.266,0.260,0.281$, and 0.223 respectively. The negative value of the path coefficient from DS to JS (ie $\rho_{31}=-$ 0.352 ) indicated that the higher the principal directive leadership scores the lower the job satisfaction.

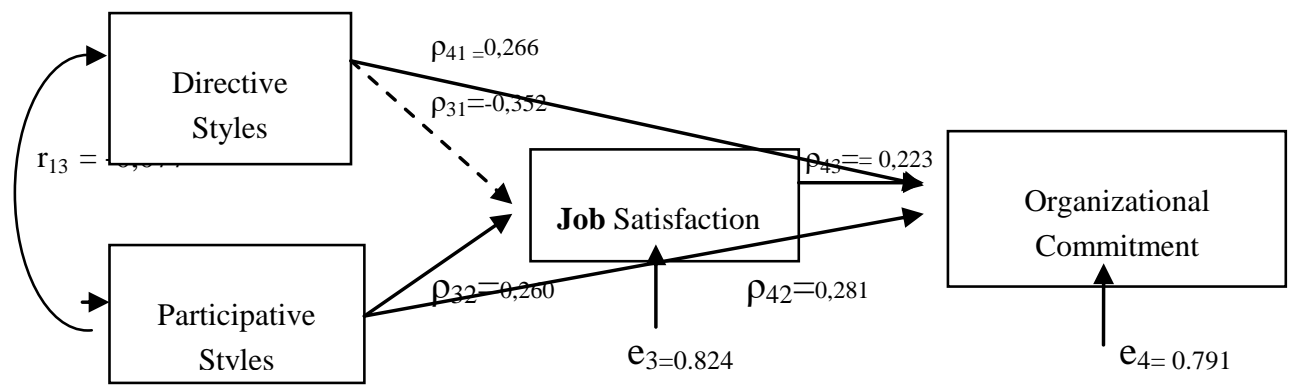

Figure 5

Path Diagram of the Empirical Model 


\section{Sub-structure 1: Hipotesis 1 and 2}

Path coefficients (ij) of the empirical model between the variables were presented in Figure 6 and the significance test listed in sub-structure-1 presented in the Table 4.

Figure 6

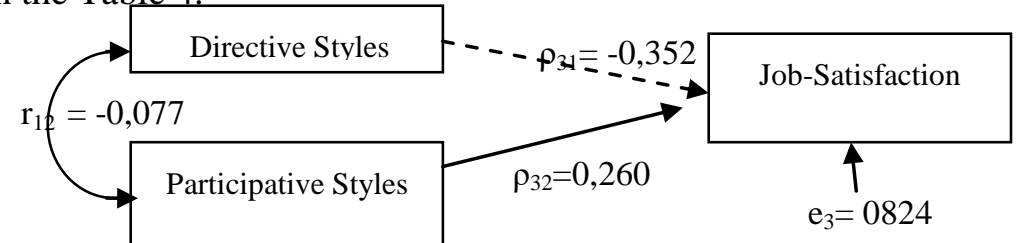

Enpirical Model of Sub-Structure- 1

Table 4

Sub Structure-1: Hypothesis Testing

\begin{tabular}{|c|c|c|c|c|c|c|}
\hline \multicolumn{2}{|c|}{ Model } & \multicolumn{2}{|c|}{ Unstandardized Coefficients } & Standardized Coefficients & $\mathrm{t}$ & Sig. \\
\hline \multirow{4}{*}{1} & & B & Std. Error & Beta & & \\
\hline & (Constant) & 3,217 & 286 & & 11,267 & ,000 \\
\hline & $\mathrm{X}_{1}$ &,- 337 &, 069 &,- 352 & $-4,899$ &, 000 \\
\hline & $\mathrm{X}_{2}$ & ,265 &, 073 & 260 & 3,626 &, 000 \\
\hline
\end{tabular}

a. Dependent Variable: $X_{3}$

As shown in the Table 4 above, the calculated value of $t=-4.89$ with a significant level of $<0.01$ determined that Ho: $\rho_{31}=0$ was rejected. It means that the principal's DS negatively affected the JS $(-35.2 \%)$. For hypothesis 2 , the calculated value of $t=3.62$ with a significant level of $<0.01$ so that, Ho: $\rho_{32}=0$ was rejected. As a result, it can be concluded that the PS directly affected the principal's JS (26.0\%).

Test results of sub-structure 1 indicated that the school principal's PS was an important factor that positively affected JS of the school principal, but on the other hand, DS had a negative influence on the principal JS.

Sub-Structure- 2: Hypotheses 3, 4, and 5.

Path coefficients (ij) of the empirical model between the variables investigated were presented in Figure 7 and the hypothesis test of sub-structure 2 was presented in Table 5 .

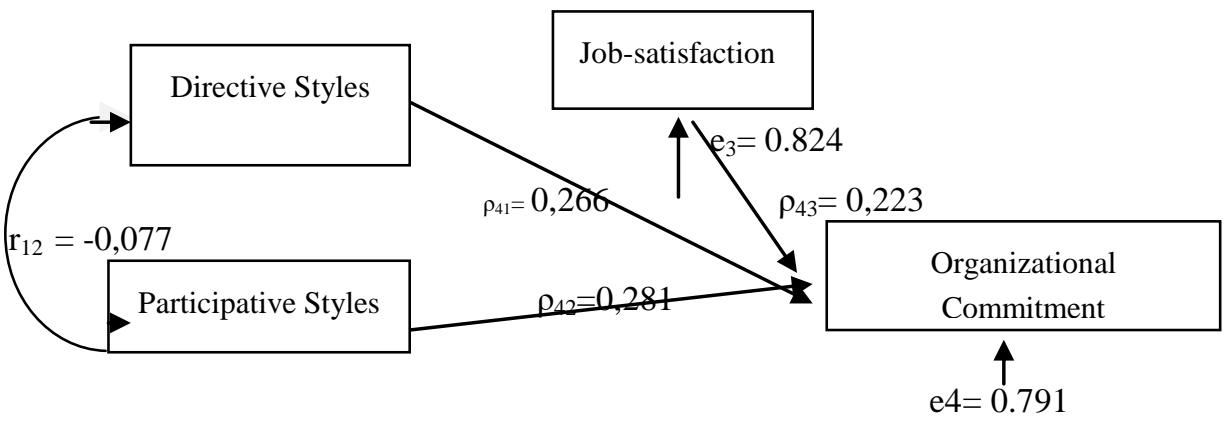

Figure 7

Empirical model of the sub-structure 2 
Table 5

Hypothesis Testing of the Sub-Structure-2

\begin{tabular}{|c|c|c|c|c|c|c|}
\hline \multirow{2}{*}{\multicolumn{2}{|c|}{ Model }} & \multicolumn{2}{|c|}{$\begin{array}{l}\text { Unstandardized } \\
\text { Coefficients }\end{array}$} & \multirow{2}{*}{$\begin{array}{l}\text { Standardized } \\
\text { Coefficients } \\
\text { Beta }\end{array}$} & \multirow[t]{2}{*}{$\mathrm{t}$} & \multirow[t]{2}{*}{$\begin{array}{l}\text { Sig } \\
.\end{array}$} \\
\hline & & B & $\begin{array}{l}\text { Std. } \\
\text { Error }\end{array}$ & & & \\
\hline \multirow[t]{4}{*}{2} & (Constant) & 1,079 & ,362 & & 2,976 & ,003 \\
\hline & $\mathrm{X}_{1}$ &, 245 & ,070 & ,266 & 3,502 & ,001 \\
\hline & $\mathrm{X}_{2}$ & ,276 & 072 & ,281 & 3,817 & ,000 \\
\hline & $X_{3}$ & ,214 & 075 & ,223 & 2,862 &, 005 \\
\hline
\end{tabular}

a. Dependent Variable: $\mathrm{X}_{4}$

From Table 5, for hypothesis 3 we get the $t_{\text {cal }}=3.50$ with a significance level of $<0,01$ so that, Ho: $\rho 41=0$ was rejected. This means that the principal's DS had a positive direct effect (equal to $26,2 \%$ ) to the principal's OC. For hypothesis 4 , the calculated value of $\mathrm{t}_{\text {cal }}=3.81$ with a significant level of $<0.01$ so that, Ho: $\rho_{42}=0$ was rejected. This means that the school principal has a direct positive effect $(28.1 \%)$ significantly toward the principal's OC.

For hypothesis 5 , the calculated value of $\mathrm{t}_{\text {cal }}=2.86$ with a significant level of $<0.01$, as a result it rejected Ho: $\rho_{43}=0$. This means that JS had a significant positive direct effect $(22.3 \%)$ toward OC. The result of the three hypotheses test in the sub-structure showed that the DS, PS, and JS have a direct positive effect on OC of the school principal. The higher the intensity of the three variables will have a positive effect on the principal organizational commitment. The direct effect of the principal DS towards JS and OC was $-35.2 \%$ and $26.6 \%$ respectively. The direct effect of principal's JS towards OC was $22.3 \%$.

\section{Sub-Structure-3: Hypothesis 6 and 7.}

Path coefficients (ij) of the empirical model between the variables investigated were presented in Figure 8. The indirect effect of Participative leadership Style on OC was 5.8\%. Therefore, the Principal Participative Style has a moderate indirect effect through Job Satisfaction on the Organizational Commitments, and it could be seen that job Satisfaction as a mediator for the organizational commitments. The indirect effect of Directive leadership Style on Organizational Commitment through Job-satisfaction was $=-0,078$. It means that Job-satisfaction could not serve as a mediator of Directive Leadership Style towards the organizational commitments. So the total effect of DS towards OC was $18.8 \%$ and the total effect of PS on OC was $33.9 \%$.. The direct, indirect, and non-path effects between the variables were presented in Table 6, and the hypothesis test of substructure 3 was presented in the Figure- 8 below: 


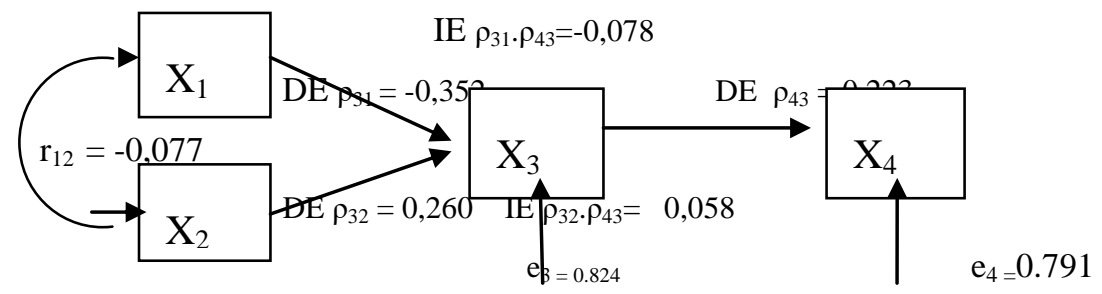

Figure 8.

Empirical Model of the Sub-structure-3.

Table 6

Direct and indirect effect values

\begin{tabular}{|c|c|c|c|c|c|c|}
\hline \multirow[t]{2}{*}{ Model } & \multirow[t]{2}{*}{ Variables } & \multicolumn{2}{|c|}{ Causal Effects } & \multirow[t]{2}{*}{ Total } & \multirow[t]{2}{*}{ Spurious } & \multirow[t]{2}{*}{$r_{x y}$} \\
\hline & & $\mathrm{DE}$ & $\mathrm{IE}$ & & & \\
\hline \multirow{2}{*}{$\begin{array}{l}\text { Sub } \\
\text { Structure-1 }\end{array}$} & $X_{1}$ and $X_{3}$ & $\rho_{31}=-0,352$ & - & $\rho_{41}=-0,352$ & 0,022 & $-0,330$ \\
\hline & $X_{2}$ and $X_{3}$ & $\rho_{32}=0,260$ & - & $\rho_{42}=0,260$ & $-0,029$ & 0,231 \\
\hline \multirow{3}{*}{$\begin{array}{l}\text { Sub } \\
\text { Structure-2 }\end{array}$} & $X_{1}$ and $X_{4}$ & $\rho_{41}=0,266$ & $\rho_{31} \cdot \rho_{43}=-0,078$ & $\rho_{41}+\left(\rho_{31} \cdot \rho_{43}\right)=0,188$ & $-0,089$ & 0,355 \\
\hline & $X_{2}$ and $X_{4}$ & $\rho_{42}=0,281$ & $\rho_{32 .} \rho_{43}=0,058$ & $\rho_{42}+\left(\rho_{32} \cdot \rho_{43}\right)=0,339$ & 0,014 & 0,295 \\
\hline & $\mathrm{X}_{3}$ and $\mathrm{X}_{4}$ & $\rho_{43}=0,223$ & -- & $\rho_{43}=0,223$ & $-0,023$ & 0,200 \\
\hline
\end{tabular}

\section{DISCUSSION}

The results showed that the principal directive leadership style had a negative effect $\left(\rho_{31}=-0.352\right)$ on the job-satisfaction but positively correlated with the principal organizational commitment $\left(\rho_{41}=0.260\right)$. The directive leadership style and job satisfaction were not synergistically enhancing the principal's organizational commitment. As stated before that the higher the intensity/leadership scores of the principal's directive leadership, the lower the organizational commitment. This is also relevant to Robbin (2008), Thian (2014) and Murdoch (2013).In addition, Norazah \& Norbayah, (2011) stated that directive leadership styles are not appropriately implemented in structured and routine work, and directive leadership styles are negatively correlated with organizational commitment. Generally, teacher tasks are structured and routinely organized so that the principal's dissatisfaction usually emerges from his/her co-workers, in which the teachers do not in line with the school principal's expectation, or due to the fact that the principal lacks of two-way communication, as a result teacher's opinions or ideas in decision making would not be taken into account.

In contrast, it was found that the participative leadership was significantly positively correlated with job satisfaction $(29.1 \%)$ and principal organizational commitment (22.3\%). The study was in accordance with the findings reported by Malik et al., (2013); Somech (2005); Hui et.al., (2014). As long as the leaders adopting participatory styles, they could be able to increase job satisfaction (Maqsood, et.al., 2013) in which the satisfaction was considered as a mediator of leadership style with organizational commitment (Ismail \& Daud, 2014). As a result, workers who have high job 
satisfaction result in higher organizational commitment (Khan, Rao \& Usman et al. 2017). In line with this findings, it was shown that principal's leadership style was generally considered as the key in building positive relationships in schools (Neil \& Prater, 1999) and it played an important role in shaping a better conditions within organizations to achieve organizational goals (Rotich \& Kipkoech, 2012).

Job satisfaction did not function positively as a moderator for influencing the directive leadership style toward the principal organizational commitment. This could be seen from the direct effect of the headmaster directive leadership style toward organizational commitment was $26.6 \%$ but indirect effect (through job satisfaction) was $-7.8 \%$. However, it was found that job satisfaction served as a moderator for the participative leadership towards organizational commitment. The direct effect of participative leadership style toward OC was $28.1 \%$ and increased to $33.9 \%$ through job satisfaction, and greater than the direct effect of job satisfaction on organizational commitment, $\mathrm{i} e$ $22.3 \%$. The results indicated that, participative leadership style can improve principal's job-satisfaction and organizational commitment. As it is known that organizational commitment and job satisfaction are seen as indicators of the success of an organization that shows loyalty and willingness to work hard (Colquit, 2009; Malik, et.al., 2010; Luthan, 2006). It was also found that interpersonal relationship satisfaction is considered as a precursor of organizational commitment and it primarily mediates its relationship with variety of tasks and scope of work of employees (Leite, Rodrigues \& Albuquerque, 2014).

Succession of the headmaster leadership needs to pass down to ensure future leadership needs (Fraser \& Brock, 2013) and support the improvement of high school principal competency (Presidential Instruction No. 1 of 2010) and the ability of a principal to cooperate with others effectively and efficiently ((Maizirwan., 2014)). Teaching experience is not the only benchmark for appointing school principals, and so far promotion requirements for the principals position has not been based on the skills required (Mulyasa, 2013). Therefore, the government needs to change the policy to prepare prospective school leaders through a recruitment or selection process that is ability to performing managerial practices to achieve school goals (Arikewuyo, 2009; Faith \& Kenneth, 2012; Dude, 2012). This policy needs to implement in order to prepare qualified principals to support improving the quality of education (Mitgang, 2012). The participative leadership of the school principal is capable of supporting its function to create professional ethos in schools (Arikewuyo, 2009), fulfill the role of intermediary, informational, decision maker (Wahjosumijo,2002), and fair and decisive decisions (Usman, 2008; Vishal \& Syalendra, 2013).

Based on the results above it can be used to propose a model of job satisfaction development of the junior high school principal organizational commitment as shown in Figure 8. This model can be used as a consideration in recruitment policy of teachers who are going to promote as school principals. This policy could be implemented to get qualified principals to support improving the quality of education (Mitgang, 2012). By carrying out teacher selective recruitments, it could reduce government spending in teacher training for preparing future qualified school principals. 


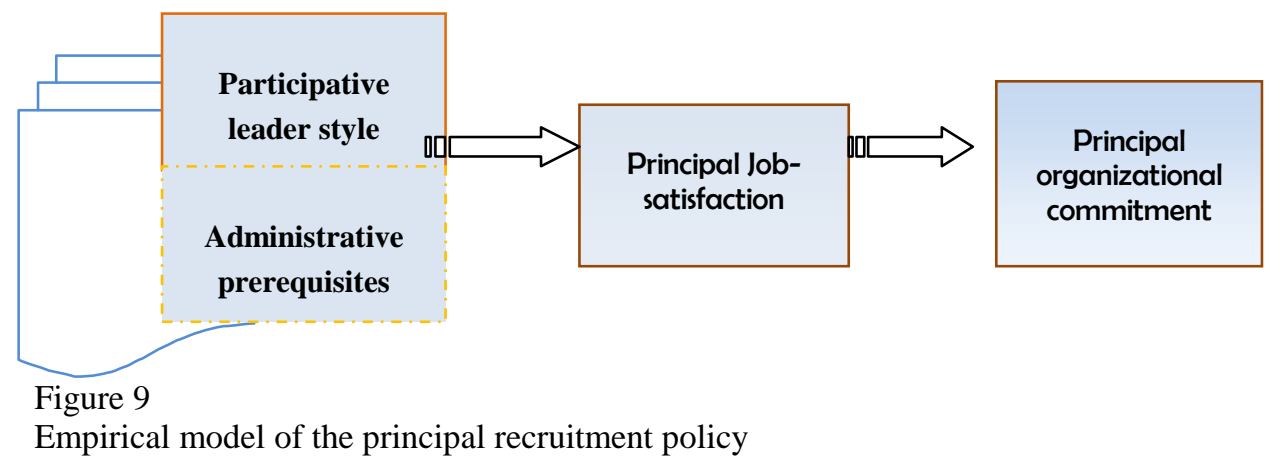

The relationship between leadership style and the headmaster's commitment fosters: the desire to remain in an organization, strives for organizational/school progress, as well as acceptance of organizational/school values and goals (Mowday, Steers \& Porter, 1979) Internal and external factors affecting subordinate teacher job-satisfaction are situational factors that need to be considered by the headmasters to sort and choose a leadership style relevant to the organization Lusser, (1997) and this should be supported by the participative leadership style of the headmaster. Participative leadership style can create a conducive working atmosphere, make good communication with the teachers, and appreciate the ideas and opinions of teachers in decision making.

\section{CONCLUSIONS}

Based on the results and discussion above, it is concluded that Directive leadership style has a significant effect on organizational commitment, but negatively affects the job satisfaction of the junior high school principals. In addition, it was also found that, Participatory leadership style has a significant positive effect on job satisfaction and organization commitment of the school principals. It turns that job satisfaction has a significant effect on the headmaster organization commitment. However, Job satisfaction does not work positively as a mediator for the relationship between directive leadership style and headmaster organization commitment. It functions as a positive mediator between the participative leadership style and the headmaster organization commitment. Therefore, it is concluded that job-satisfaction could be used as mediator between participative leadership style and organizational commitments in predicting school principal achievements in promoting and developing school organizations. And the findings showed that empirical model could be used as reference for the principal recruitment policy and could reduce recruitment costs relatively.

\section{RECOMMENDATION}

It is recommended that government policy in recruiting teachers who are going to promote into a junior high school principal, needs to consider his/her leadership style, job-satisfaction and organizational commitment, because it supports to their leadership achievements. It is preferred that the principal has participative leadership styles. 


\section{ACKNOWLEDGMENT}

I would like to thank the General Directorate of Higher Education of The Republic of Indonesia for funding this research, and also thank to the Staffs of the Research Board of the state University of Medan.

\section{REFERENCES}

Arikewuyo, M.O. (2009). Professional Training of Secondary School Principals in Nigeria - A Neglected Area in the Educational System. Florida Journal of Educational Administration\& Policy, 2 (2), 73-84.

Bahrumsyah. (2009). "Kebijakan Dinas Pendidikan Propinsi Sumatera Utara dalam Meningkatkan Kompetensi Guru Bermuatan Soft Skill”. (Makalah) Disampaikan dalam Seminar Internasional Universitas Negeri Medan. Medan.

Bell, C.C. (2014). The Impact of Participative and Directive Leadership on Organisational Culture: An Organisational Development Perspective. Mediterranean Journal of Social Sciences, 5(23), 5-16.

Benoliel, P.S. (2010). Who Benefit from Participative Management - University of Haifa. Journal of Educational Administration, 48(3), 285-308 file://C:/Users/Senang/Downloads/Who_benefits_from_participative_management.pdf

Bintang, S. (2011). Pengaruh Motivasi, Wewenang, dan Komitmen Organisasi terhadap kinerga Kepala sekolah SMP kota Medan . Kerjasama Disdik Pempropsu dengan Pascasarjana Unimed. Medan.

Bogler, R. (2002). The influence of Leadership Style on Job Satisfaction. Educational Administration Quarterly, 23 (3), 31-48.

Cemaloglu, N., Sezgin, F., \& Kilinc, Ç,A. (2012). Examining the Relationships Between School Principals Transformational and Transsactional Leadership Styles and Teachers Organizational Commitment. . The Online Journal Of New Horizons In Education (TOJN), 2(2), 1-12.

Clark, F. (1996). Leadership Quality, Strategies for Action. London: Mc Graw-Hill Book Com.

Cokluk, O., \& Yilmaz, Y. (2010). The Relationship Between Leadership Behaviour and Organization Commitment in Turkish Primary School. Bilig-Summer, 54, 75-94.

Colquit, J.A., Le Pine, J.A., \& Wesson, J.M. (2009). Organizational Behavior, Improving Performance and Commitment in the Workplace. Singapore: McGraw-Hill International Edition.

Daft, R.L, (2005). The Leadership Experience. Owen Graduate School Management. Vanderbilt University. International student edition. Thomson South-west. Canada: DPS Associate, Inc. 
Dramstad, S. (2004). Job Satisfaction and Organizational Commitment Among Teachers in Norway : A Comparative Study of Selected Schools From Public and Private Educational Systems. Andrews University Digital Commons.

Dude, D.J. (2012). Organizational Commitment of Principals: The Effects of Job Autonomy, Empowerment, and Distributive Justice. Theses and Dissertation, Iowa Research Online. Iowa State, USA.

Edmondson, A.C. (1999). Psychological Safety and Learning Behavior in Work Teams. Administrative Science Quarterly, 44 (2), 350-383.

Faith, O.C. (2013). The Influence of Principals' Leadership Styles on Secondary School Teachers' Job Satisfaction. Journal of Educational and Social Research, 2 (9), 45-52.

Fraser, J., \& Brock, B.L. (2013). Catholic School Principal Job Satisfaction: Keys to Retention and Recruitment. Catholic Education. A Journal of Inquiry and Practice, 9 (4), 424-440.

Getahun, T.B. (2016). Teacher's Job Satisfaction And Its Relationship With Organizational Commitment In Ethiopian Primary Schools: Focus On Primary Schools Of Bonga Town. European Scientific Journal, 12(1), 1-22. https://eujournal.org/index.php/esj/article/view/7480

Gilbreath, G. (2013). Supervisor and Employee Presenteeism. International Journal of Leadership Studies , 7 (1), 114-131.

Gipson, J. L. (2006). Organisas (Translated edition). Jakarta: Erlangga Publisher.

Gipson, J.L., Ivancevich, J.M., \& Donnelly, P. (1996). Organisasi Perilaku Struktur dan Proses . (Translated edition). Jakarta, West Java, Indonesia: Erlangga Publisher.

Hirsch, E., Emerick,S., \& Church, S.K. et al. (2006). Teacher Working Conditions Are Student Learning Conditions: A Report on the 2006 North Carolina Teacher Working Conditions. North Carolina: https://files.eric.ed.gov/fulltext/ED498770.pdf

House, R.J., \& Mitchell, T.R. (1974). Path-Goal Theory of Leadership. Journal of Contemporary Business, 5 (3), 81-97.

Huang, T. (2011). The relationship between headmasters' leadership behaviour and teachers commitment in primary schools in the district of sarikei, Sarawak. International Conference on Education and Educational Psychology (ICEEPSY 2011). 29,1725 1732. SciVerse Science Direct, Procedia - Social and Behavioral Sciences.

Hui.H., Jenatabadi, H. S., Ismail, N. A., \& Radzi, M. (2013). Principals Leadership Style and Teacher Job Statisfaction : A Case Study in China. Interdisciplinary Journal of Contemporary Research in Business, 5 (4), 175-184.

Ismail, I.B., \& Daud. Y. (2014). Teacher's Job Satisfaction As a Mediator of The Relationship between Ethical Leadership and Organizational Commitment in School. International Journal Of Scientific Research and Education, 2 (8), 1729-1740. 
Jalilizadeh, M., Abbasi, H., \& Mohammadi, S. (2013). The Relationship Between Principals Leadership Styles with Performance of Physical Education Teachers in Secondary Schools in Western Provinces of Iran. Asian Journal of Management Sciences \& Education, 2(4), 1-7.

Khan, R.R. (2017). The Mediating Role of Job Satisfaction between Transformational Leadership and Organizational Commitment within the SMEs of Karachi. International Journal of Applied Business and Management Studies (IJAB, 2 (1), 1-13.

Leite, N.R.P., Rodrigues, A.C.D., \& Albuquerque, L.G (2014). Organizational Commitment and Job Satisfaction: What Are the Potential Relationships?. BAR Brazilian Administration Review, 14 (4), 476-495.

Lusser, R.N. (1997). Management (Concept, Aplications,Skill Development). Ohio: Western College Pub.

Luthan, F. (1998). Organizational Behavior. Singapore: Mc.Graw Hill Inc.

Luthan, F. (2006). Perilaku Organisasi, (translated edition). Yogyakarta: Andi Publisher.

Mahdi, O.R., Gulam, S., \& Almsafir, M.K. (2014). Empirical Study on the Impact of Leadership Behavior on Organizational Commitment in Plantation Companies in Malaysia. Procedia-Social Behavioral Sciences, 109, 1076-1087.

Maizirwan. (2014). Analisis Kebijakan Persyaratan Calon Kepala Sekolah. Retrieved June 27th, 2017, from https://wordpress.com/2012/06/28

Malik, M., Naswab, S., Naeem, B., \& Danish, R.C. (2010). Job Satisfaction and Organizational Commitment of University Teachers in Public Sector of Pakistan. International Journal of Business and Management, 5 (6), 17-26.

Maqsood, S.B. (2013). Managers Leadership and Employees Satisfaction. Human and Social Science Research (HSSR), 1 (2), 139-144.

Meyer, J.P., \& Allen, N.J. (1991). A three-component conceptualization of organizational commitment. Human resources Management, 1 (1), 61-89..

Mitgang, L. (2012). The Making of The Principal. Five Lessons in Leadership Training. New Jersey: The Wallace Foundation.

Mowday, R.T., Steer, R.M., \& Porter, L.W. (1979). The Measurement of Organizational Commitment.r. Journal of Vocational Behavior, 14 (2), 224-247.

Mulyasa, H.E. (2013). Manajemen \& Kepemimpinan Kepala Sekolah. Jakarta: Bumi Aksara Publisher.

Murdoch, L. (2013). An Invertigation of Path-Goal Theory, relationship of Leadership Style, Supervisor-Related Commitment, and Gender. Emerging Leadership Journal (ELJ), $6(1), 13-44$. 
Nadarasa, T., \& Thuraisingam, R. (2014). The influence of Principals' Leadership Styles on School Teachers' Job Satisfaction- Study of Secondary School in Jaffna District. International Journal of Scientific andResearch Publication, 4 (1), 1-7. http://www.ijsrp.org/research-paper-0114/ijsrp-p2502.pdf

Neil, A.J. (1999). Teacher and Principal Differ on The Seriousness of School Discipline- A National Perspective. National Forum of Applied Educational Research Journal, 12 (3), 1-7.

Norazah, M.S. (2011). Job Satisfaction and Organizational Commitmen - The of The Gender In. International Journal of Psychology Researc, 6 (5), 1-15.

Nuh, M. (2011). Nilai Kemampuan Managerial Kepala Sekolah Rendah. Jakarta: Retrieved on November, $1^{\text {st }} 2016$, from http://www.republika.co.id/berita.

Patrick, A. (2007). Examination of Teacher Workplace Satisfaction and Student Achievement. Retrieved from Electronic Theses and dissertation.: https://digitalcommons.georgiasouthern.edu/cgi/view content.cgi

Rani, F.D. (2013). Situational Leadership -An Emergingtrend of Leadership Style - A Case of Software Industry. Internationa Journal of Emerging Research in Management \& Technology, 1 (3), 1-16.

Reza, O. (2013). Leadership Style, Organizational Commitment and Job Satisfaction - A case Study on HighSchool Principals in Tehran Iran. American Journal of Humanities and Social Sciences, 1 (4), 263-267.

Robbin S,P., \& Coulter, M. (2007). Management (9th-ed ed.). Canada: Person Prentice Hall.

Robbin S,P., \& Judge, T. (2005). Perilaku Organisasi (ed. terjemahan) (translated edition), Jakarta: PT. Salemba Empat.

Robbin S,P. (2008). Perilaku Organisas (translated edition), Jakarta: PT. Indeks.

Rotich, E.J. (2012). The Role of the School Principal in the Implementation of the Free Secondary Education. International Journal of Academic Research in Progressive Education and Development, 1 (3), 120-132.

Rotich, E.J. (2012). The Role of the School Principal in the Implementation of the Free Secondary Education. International Journal of Academic Research in Progressive Education and Development, 1 (3), 120-132.

Shan, M. (1998). Professional commitment and satisfaction among teachers in Urban middle schools. Journal of Educational Research, 92, 67- 73.

Silong, A.D. (2009). Participative and Effective Community Leadership Practice in Malaysia. The Journal of Human Resource and Adult Learning, 5 (1), 139-14. 
Somech, A. (2005). Directive versus Participative Leadership - Two Complementary Approaches to Managing School Effectiveness. Educational Administration Quarterly, 45 (1), 777-800.

Stogkard, J., \& Leman, M.B. (2004). Influences on the Satisfaction and Retention of 1st-year Teachers . Educational Administration Quarterly, 40 (5), 742-771.

Sudarmin, D. (2012). Visi Baru Manajemen Sekolah (dari Unit Birokrasi ke Lembaga Akademik). Jakarta, Indonesia: PT. Bumi Aksara.

Sušanj, Z., \& Jakopec, A. (2012). Fairness Perceptions and Job Satisfaction as Mediators of the Relationship between Leadership Style and Organizational Commitment. Psychological Topic, 21 (3), 509-526.

Sweeney, J.T., \& Quirin, J.J. (2009). Accountants as layoff survivors. A research note. Accounting, organizations and society, 34, 787-795.

Tain-Fung, W., Mei-Hui, T., Yeh-Hsun, F \& Wu, R.T.Y. (2006). A Study of the Relationship between Manager's Leadership Style and Organizational Commitment in Taiwan's International Tourist Hotels. Asian Journal of Management and Humanity Sciences, http://210.60.31.132/ajmhs/no3/05-mhs06023.pdf, 1 (3), 434-452.

Thian, T.L. (2014). School Principal Leadership Styles and Teaher Organizational Commitment Among Performing School . Proceding-5th International Converence on Business and Economic Research, 10, 24-25. Pullman Hotel, Kucing-Sarawak, Malaysia .

Usman, H. (2008). Manajemen (Teori, Praktek \& Riset Pendidikan). Jakarta: Bui Aksara publisher.

Veithzal, R., \& Mulyadi, D. (2011). Kepemimpian dan Perilaku Organisasi (translated edition). Jakarta, Rajawali Press.

Vishal, G., \& Syalendra, S. (2013). An Empirical Study of the Dimensionality of Organizational Justice and Its Relationship with Organizational Citizenship Behavior in the Indian Context. International Journal of Human Resource Management, 24 (6), 1227-1229.

Wahjosumijo. (2002). Kepemimpinan Kepala Sekolah. Jakarta: PT Raja Grafindo.

Zurnali, C. (2010). Learning Organization, Competency, Organizational Commitment and Customer Orientation : Knowledge Worker - Kerangka Riset Manajemen Sumberdaya Manusia di Masa Depan. Bandung: Unpad Press Publisher. 